\title{
Antioxidant Status of Vigna mungo L. in Response to Sulfur Nutrition
}

\author{
Neelam Chandra and Nalini Pandey \\ Plant Nutrition and Stress Physiology Laboratory, Department of Botany, University of Lucknow, Lucknow 226007, India \\ Correspondence should be addressed to Neelam Chandra; death2eternity@gmail.com
}

Received 19 November 2013; Accepted 13 December 2013; Published 18 February 2014

Academic Editors: M. Lehmann and J. Zhang

Copyright (C) 2014 N. Chandra and N. Pandey. This is an open access article distributed under the Creative Commons Attribution License, which permits unrestricted use, distribution, and reproduction in any medium, provided the original work is properly cited.

Black gram (Vigna mungo L. var. DPU-88-31), an edible legume, was grown at 1,2, 4, 6, and 8 meq S L ${ }^{-1}$ to study the effect of deficient and excess level of sulfur on oxidative metabolism. Plants supplied by 4 meq S L ${ }^{-1}$ showed optimum yield. Sulfur deficient plants (1 and $2 \mathrm{meq} \mathrm{S} \mathrm{L}^{-1}$ ) showed reduction in growth and chlorosis of young leaves. Tissue sulfur and cysteine concentration was increased with increasing sulfur supply. The thresholds for critical concentration of sulfur deficiency and toxicity were $0.315 \%$ and $0.434 \%$ dry weight. Biomass and photoassimilatory pigments were decreased and carbohydrates (sugar and starch) were accumulated in leaves of sulfur deficient and excess plants. Accumulation of hydrogen peroxide and thiobarbituric acid reactive substances in sulfur deficient and excess plants caused oxidative damage in plants which was also evident by the increase in the activity of superoxide dismutase, catalase, peroxidase, ascorbate peroxidase, glutathione reductase, and concentration of ascorbate and nonprotein thiols.

\section{Introduction}

Sulfur is an essential macronutrient required for plant growth and development of plants. Sulfur is found in nature in many different oxidation states in inorganic, organic, and bioorganic forms but is mainly taken up by the plant as inorganic sulfate from the soil. Sulfur deficiency is found all over the world including India and causes heavy losses in crop yield due to its role in metabolism. Sulfur stress affects metabolic and physiological activities of plants. Carbohydrate (sugars and starch) metabolism is also affected by sulfur nutrition. Sugars were decreased and starch was found to be accumulated in leaves of sulfur deficient plants [1]. Sulfur is a constituent of essential compounds such as cysteine, methionine, several coenzymes (biotin, coenzyme A, thiamine pyrophosphate and lipoic acid), thioredoxins, and sulfolipids. Cysteine is required for protein and glutathione (GSH) synthesis or functions as a sulfur donor for methionine and secondary metabolite biosynthesis [2]. Glutathione helps control the concentration of the reactive oxygen species (ROS) and participates in the regulation of sulfate uptake and in detoxification of heavy metals [3].
Plants exposed to abiotic stress invariably show marked alterations in the electron transport in both chloroplast and mitochondria leading to formation of reactive oxygen species (ROS) which are partially reduced forms of atmospheric oxygen [4]. They are formed from excitation of $\mathrm{O}_{2}$ to form singlet oxygen $\left(\mathrm{O}_{2}{ }^{1}\right)$ or from the transfer of one, two, or three electrons to $\mathrm{O}_{2}$ to form superoxide $\left(\mathrm{O}_{2}{ }^{--}\right)$, hydrogen peroxide $\left(\mathrm{H}_{2} \mathrm{O}_{2}\right)$, or a hydroxyl radical $\left(\mathrm{OH}^{-}\right)$. Accumulation of active oxygen species, resulting in oxidative stress, is a common feature of several types of abiotic stress including deficiency or excess of nutritional element [5]. Increment of ROS results in membrane damage which further affects vital cellular components like lipids, proteins, and nucleic acids [6].

The ROS are scavenged by enzymatic and nonenzymatic defense systems [7]. Major ROS scavenging enzymes are superoxide dismutase (SOD), ascorbate peroxidase (APX), glutathione reductase (GR), and catalase (CAT). SOD accelerates the formation of hydrogen peroxide which is decomposed by catalase [8]. Catalase is present in peroxisomes and responsible for removal of excess $\mathrm{H}_{2} \mathrm{O}_{2}$ during stress. Ascorbate peroxidase (APX) breaks down $\mathrm{H}_{2} \mathrm{O}_{2}$, especially in chloroplast where it may cause damage to photosynthesis 
machinery [9]. Glutathione reductase (GR) is essential for the reduction of oxidized glutathione by $\mathrm{NADH}[10]$.

Ascorbate and glutathione both are involved in antioxidative defense system via the ASH-GSH cycle [11]. Ascorbate and glutathione can scavenge ROS nonenzymatically. Ascorbate reacts directly with hydroxyl radicals, superoxide and singlet oxygen and also reduces the oxidized form of $\alpha$-tocopherol, an important antioxidant [12]. Glutathione (GSH) helps control the concentration of the ROS $[3,10]$.

There are very few reports on antioxidative response of plants to sulfur stress and most reports available are on the oxidative damage caused by $\mathrm{SO}_{2}$ exposure. Changes in SOD were observed in pea cultivars exposed to $\mathrm{SO}_{2}$. Increase in the concentration of antioxidants especially glutathione and in the activities of enzymes superoxide dismutase (SOD) and glutathione reductase (GR) involved in protection from oxidative stress were reported in wheat plants subjected to $\mathrm{SO}_{2}$ fumigation [13]. A decrease in GSH in sulfur deficient rice plants and an upregulation of the enzymes monodehydroascorbate reductase (MDHAR), ascorbate peroxidase (APX), and glutathione reductase [1] were reported. In this study the effect of both sulfur deficient and excess on the oxidative metabolism and antioxidative defense system in black gram plants has been addressed for the first time and it is proposed to see how the oxidative metabolism is affected by both stresses. The critical limits for deficiency and toxicity and the effect of sulfur on yield and carbohydrates were also determined.

\section{Materials and Methods}

Plants of black gram (Vigna mungo L. var. DPU-88-31) were grown in sand culture as explained in [14]. Prior to sowing, the seeds were surface sterilized with $5 \%(\mathrm{v} / \mathrm{v})$ mercuric chloride solution and then with distilled water. The nutrient solution was composed of $4 \mathrm{mM} \mathrm{KNO}, 4 \mathrm{mM} \mathrm{Ca}\left(\mathrm{NO}_{3}\right)_{2}$, $2 \mathrm{mM} \mathrm{MgSO}_{4}, 1.33 \mathrm{mM} \mathrm{NaH} \mathrm{PO}_{4}, 0.33 \mu \mathrm{M} \mathrm{HBO}_{3} 0.1 \mathrm{mM}$ Fe EDTA, $10 \mu \mathrm{M} \mathrm{MnSO}_{4}, 1 \mu \mathrm{M} \mathrm{CuSO}_{4}, 1 \mu \mathrm{M} \mathrm{ZnSO}_{4}, 0.1 \mu \mathrm{M}$ $\mathrm{Na}_{2} \mathrm{MoO}_{4}, 0.1 \mu \mathrm{M} \mathrm{NaCl}, 0.1 \mu \mathrm{M} \mathrm{CoSO}$, and $0.1 \mu \mathrm{M} \mathrm{NiSO}_{4}$. Sulfur was supplied as $\mathrm{Na}_{2} \mathrm{SO}_{4}$ at varying levels ranging from $1,2,4,6$ and 8 meq S L ${ }^{-1}$. In sulfur deficient plants, magnesium was compensated by magnesium chloride. The experiment was conducted in randomized complete design with three replicates and during the period in which the experiment was conducted light intensity ranged between 745 to $865 \mu \mathrm{mol} \mathrm{m}-2 \mathrm{~s}-1$ at 12:00 noon, minimum and maximum temperature ranged between $20-27^{\circ} \mathrm{C}$ and $35-42^{\circ} \mathrm{C}$.

After the appearance of symptoms ( 25 days of treatment) experimental analysis was carried out to determine the response of variable sulfur supply on growth, biomass, tissue sulfur, carbohydrates, cysteine, proteins, photoassimilatory pigments, $\mathrm{H}_{2} \mathrm{O}_{2}$ (hydrogen peroxide), thiobarbituric reactive substances (TBARS), antioxidative enzymes (SOD, CAT, POD, APX, and GR), nonenzymatic antioxidants ascorbate (ASC), and nonprotein thiols (NPT).

Before taking the biomass, plant parts (leaves, stem, and roots) were separated and thoroughly washed to remove surface contamination and then finely chopped. The biomass was determined after drying the fresh material in a forced drought oven at $70^{\circ} \mathrm{C}$ for 48 hours. The oven dried plant materials were weighed accurately and wet-digested in nitric and perchloric acid $(10: 1 \mathrm{v} / \mathrm{v})$ in a hot plate. After digestion, tissue sulfur was estimated turbidimetrically by the method of Chesnin and Yien [15] in a reaction mixture containing sodium acetate buffer $(\mathrm{pH}=4.8), 50 \%$ glycerol, and $20 \% \mathrm{BaCl}_{2}$. After thorough shaking the optical density was recorded at $430 \mathrm{~nm}$. The threshold values for deficiency and toxicity were determined at $90 \%$ maximum yield by plotting relative yield against their sulfur concentration in leaves.

For the estimation of photoassimilatory pigments (chlorophyll and carotenoids) finely chopped leaves were ground in pestle mortar and extracted in $80 \%$ acetone with a pinch of calcium carbonate. The extract was centrifuged at $5000 \times \mathrm{g}$ in a refrigerated centrifuge and spectrophotometric measurements were made at 480 and $510 \mathrm{~nm}$ for carotenoids and 645 and $663 \mathrm{~nm}$ for chlorophylls as described by Lichtenhaler [16].

For the determination of sugar and starch leaves were properly washed and then finely chopped and fixed in boiling $80 \%$ ethanol. Sugars were estimated colorimetrically by the method of Nelson [17] at $500 \mathrm{~nm}$. Starch was estimated by the phenol method of Montgomery [18].

Cysteine concentration was estimated by the method of Gaitonde [19]. Leaves were homogenized in 5\% chilled perchloric acid. Reaction mixture contained $1 \mathrm{~mL}$ of extract, glacial acetic acid, and ninhydrin reagent. Reaction mixture was kept at $45^{\circ} \mathrm{C}$ for 20 minutes. After cooling immediately at room temperature, colour developed was read at $560 \mathrm{~nm}$.

Hydrogen peroxide $\left(\mathrm{H}_{2} \mathrm{O}_{2}\right)$ was estimated by method of Brennan and Frenkel [20]. Finely chopped leaves were ground in chilled pestle mortar in acetone and centrifuged at $10,000 \times \mathrm{g}$ for 5 minutes. The pellet was discarded. To the supernatant, titanium tetrachloride was added. The precipitate formed was solubilized in chilled liquid ammonia and centrifuged. Residue was washed with acetone to remove chlorophyll. The residue was dissolved in $2 \mathrm{~N} \mathrm{H}_{2} \mathrm{SO}_{4}$ and the colour intensity was read at $415 \mathrm{~nm}$.

Lipid peroxidation was measured in terms of thiobarbituric acid reactive substances (TBARS) formation by the method according to Heath and Packer [21]. Fresh leaves were homogenized with $0.1 \%$ trichloroacetic acid and centrifuged at $10,000 \times \mathrm{g}$. The supernatant was treated with $0.5 \%$ thiobarbituric acid (TBA) prepared in trichloroacetic acid and the mixture was incubated at $95^{\circ} \mathrm{C}$ in water bath for $30 \mathrm{~min}$. Samples were cooled immediately in ice bath and centrifuged at $10,000 \times \mathrm{g}$ for $10 \mathrm{~min}$. The absorbance was read at $532 \mathrm{~nm}$ and adjusted for nonspecific absorbance at $600 \mathrm{~nm}$. The concentration of TBARS was estimated by using the extinction coefficient of $155 \mathrm{mM}^{-1} \mathrm{~cm}^{-1}$.

Ascorbate (ASA) was assayed by extracting fresh leaf tissue in $10 \%$ TCA. To the supernatant $150 \mathrm{mM}$ phosphate buffer $\mathrm{pH} 7.4$ was added. The colour was developed by the adding of $10 \%$ TCA, $44 \%$ orthophosphoric acid, and $4 \%$ bipyridyl in $70 \%$ ethanol and 3\% ferric chloride. The samples were incubated at $37^{\circ} \mathrm{C}$ for $40 \mathrm{~min}$ and colour developed was read at $525 \mathrm{~nm}$. The protocol for nonenzymatic antioxidants (ASC and NPT) was according to Law et al. [22]. 
Nonprotein thiols were evaluated by the method of Ellman [23]. Finely chopped fresh leaf tissues were ground in chilled medium with $5 \%$ sulphosalicylic acid and homogenate was centrifuged at $10,000 \mathrm{rpm}$ for $10 \mathrm{~min}$. The reaction was carried out with the use of $10 \mathrm{mM}$ DTNB and $0.1 \mathrm{mM} \mathrm{GSH}$ (glutathione reduced). The colour intensity of extract was measured in a spectrophotometer at $412 \mathrm{~nm}$ with in $15 \mathrm{~min}$. Nonprotein thiols were determined by using formula $-(1 / 10)$ $\times(\mu \mathrm{L} \mathrm{GSH} / \mu \mathrm{L}$ Plant extract $) \times(\mathrm{O}$. D. of plant extract/O. D. of standard).

The activities of enzymes catalase (CAT) and peroxidase (POD) were assayed in the fresh leaf tissue extracts prepared in glass distilled water in the proportion $1 \mathrm{~g}$ fresh material to $10 \mathrm{~mL}$ water. Plant material was finely chopped and ground in a prechilled pestle and mortar kept in an ice bath. The extracts were filtered through twofold muslin and stored in a refrigerator prior to assay of enzyme activity. For SOD, APX, and GR, fresh leaves were homogenized with $150 \mathrm{mM}$ potassium phosphate buffer $\mathrm{pH} 7.0$ containing $1 \mathrm{mM}$ EDTA and 2\% PVP (for APX $1 \mathrm{mM}$ of ascorbate was also added). The homogenate was centrifuged at $15,000 \mathrm{rpm}$ for $10 \mathrm{~min}$. and the supernatant was used as the enzyme preparation. All enzyme preparations were made at $4^{\circ} \mathrm{C}$. The enzyme assay protocol has been described in [14].

Catalase was assayed by an adaptation of the permanganate titration method of Euler and Josephson [24]. The enzyme reaction we carried out for 5 minutes at $25^{\circ} \mathrm{C}$. The reaction mixture for enzyme assay contained $0.005 \mathrm{M}$ hydrogen peroxide in 0.025 potassium phosphate buffer $\mathrm{pH} 7.0$ and this was standardized against $0.1 \mathrm{~N} \mathrm{KMnO}_{4}$. The reaction was started by adding suitably diluted enzyme extract. After 5 minutes, the reaction was stopped by adding $2 \mathrm{~N} \mathrm{H}_{2} \mathrm{SO}_{4}$. Unused hydrogen peroxide in the reaction mixture was titrated against $0.1 \mathrm{~N} \mathrm{KMnO}_{4}$.

Peroxidase was assayed by the modified method of Luck [25]. The reaction was carried out at $25^{\circ} \mathrm{C}$. To $2 \mathrm{~mL}$ of $0.1 \mathrm{M}$ phosphate buffer $\mathrm{pH} 6.0,0.01 \% \mathrm{H}_{2} \mathrm{O}_{2}$ and $0.5 \%(\mathrm{w} / \mathrm{v}) \mathrm{p}$ phenylene diamine were added. The reaction was initiated by adding suitably diluted enzyme extract to the above and was allowed to proceed for 5 minutes. Reaction was stopped by adding $4 \mathrm{~N} \mathrm{H}_{2} \mathrm{SO}_{4}$. The reaction mixture was kept in a refrigerator for 20 minutes and then centrifuged at $4,000 \times \mathrm{g}$. The color intensity was read at $485 \mathrm{~nm}$.

The activity of superoxide dismutase (SOD) was determined by measuring the ability to inhibit the photochemical reduction of nitro-blue tetrazolium (NBT) in a reaction mixture containing $50 \mathrm{mM}$ phosphate buffer $\mathrm{pH} 7.8,13 \mathrm{mM}$ methionine, $75 \mu \mathrm{M}$ NBT, $2 \mu \mathrm{M}$ riboflavin, $0.1 \mathrm{mM}$ EDTA, and 0 to $50 \mu \mathrm{L}$ enzyme extract. Riboflavin was added last and tubes were illuminated for $10 \mathrm{~min}$. Blanks were not illuminated and the above reaction mixture without the enzyme extract developed the maximum colour at $560 \mathrm{~nm}$. One enzyme unit has been quantified on the basis of $50 \%$ inhibition of NBT [26].

Activity of APX was determined as per the method of Nakano and Asada [27]. The reaction mixture contained $50 \mathrm{mM}$ potassium phosphate buffer $\mathrm{pH}$ 7.0, $0.5 \mathrm{mM}$ ascorbate, and $0.1 \mathrm{mM}$ hydrogen peroxide. Oxidation of ascorbate was

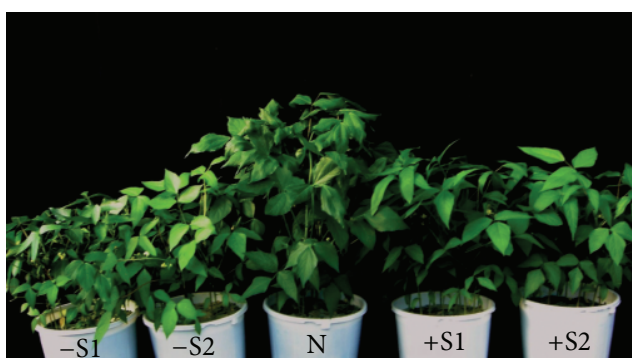

FIGURE 1: Effect of sulfur deficient $\left[-\mathrm{S} 1\left(1 \mathrm{meq} \mathrm{SL} \mathrm{L}^{-1}\right)\right.$ and $-\mathrm{S} 2$ $\left.\left(2 \mathrm{meq} \mathrm{S} \mathrm{L}^{-1}\right)\right]$ and excess $\left[+\mathrm{S} 1\left(6 \mathrm{meq} \mathrm{S} \mathrm{L}{ }^{-1}\right)\right.$ and $\left.+\mathrm{S} 2\left(8 \mathrm{meq} \mathrm{S} \mathrm{L}^{-1}\right)\right]$ supply on black gram (Vigna mungo L.) showing chlorosis, reduced growth, and leaf size in comparison to normal plants $[\mathrm{N}$ $\left(4 \mathrm{meq} \mathrm{S} \mathrm{L}^{-1}\right)$ ].

followed as fall in absorbance per min. at $290 \mathrm{~nm}$ after adding hydrogen peroxide.

Glutathione reductase (GR) assay was performed in a reaction mixture containing $100 \mathrm{mM}$ phosphate buffer $\mathrm{pH}$ 7.0, $1 \mathrm{mM}$ GSSG, $1 \mathrm{mM}$ EDTA, $0.1 \mathrm{mM}$ NADPH, and 25 to $50 \mu \mathrm{L}$ of the enzyme extract. The oxidation of NADPH was followed by monitoring the decrease in absorbance per min. at $340 \mathrm{~nm}$ [28].

2.1. Statistical Analysis. The data has been presented as the mean of observations $(n=4)$ and has been put to ANOVA. The mean values along with the least significant difference $(P \leq 0.05)$ have been presented in the tables/figures.

\section{Result and Discussion}

3.1. Plant Growth and Visible Symptoms. Maximum growth was obtained in black gram plants grown with 4 meq S L ${ }^{-1}$ and these were treated as normal plants. Plants grown at other levels of sulfur showed poor growth as compared to normal plants (Figure 1). The decrease in growth was more pronounced in deficient ( 1 and 2 meq S L ${ }^{-1}$ ) than in plants supplied excess sulfur ( 6 and $8 \mathrm{meq} \mathrm{S} \mathrm{L}^{-1}$ ). After two weeks, young leaves of sulfur deficient plants exhibited mild chlorosis which became severe after 25 days of growth. At initial stages of development, younger leaves were smaller in size and showed chlorosis in contrast to deep green of the older leaves because sulfur is less mobile in plants. Severe deficiency resulted in chlorotic patches in older leaves. This is a common pattern of symptom development in sulfur deficient plants and has been observed earlier in rice [1]. In black gram purpling on the underside of leaves was also observed. Sulfur deficiency symptoms also included restricted expansion of leaf area and elongation of internodes and thinning of stem which appeared to be thin, hard, and spindly [29]. Leaves of sulfur excess plants showed marginal chlorosis starting from apex of young leaves and dark green patches in older leaves.

3.2. Biomass and Tissue Sulfur. In plants of black gram, vegetative biomass was increased with increasing sulfur supply 
TABLE 1: Effect of sulfur supply on biomass and tissue sulfur concentration in black gram plants at 28 days of growth.

\begin{tabular}{lccccc}
\hline Plant parts & \multicolumn{5}{c}{ meq S L $^{-1}$} \\
& 1.0 & 2.0 & 4.0 & 6.0 & 8.0 \\
\hline Biomass: g plant & \\
$\quad$ & & & & & \\
$\quad$ Leaves & $0.418^{\mathrm{c}}$ & $0.516^{\mathrm{c}}$ & $0.592^{\mathrm{a}}$ & $0.551^{\mathrm{b}}$ & $0.431^{\mathrm{c}}$ \\
$\quad$ Stem & $0.250^{\mathrm{c}}$ & $0.284^{\mathrm{b}}$ & $0.367^{\mathrm{a}}$ & $0.286^{\mathrm{b}}$ & $0.260^{\mathrm{c}}$ \\
Root & $0.076^{\mathrm{c}}$ & $0.102^{\mathrm{a}}$ & $0.108^{\mathrm{a}}$ & $0.086^{\mathrm{b}}$ & $0.077^{\mathrm{c}}$ \\
Whole plant & $0.744^{\mathrm{d}}$ & $0.902^{\mathrm{b}}$ & $1.067^{\mathrm{a}}$ & $0.923^{\mathrm{c}}$ & $0.761^{\mathrm{d}}$ \\
Tisssue S: \% dry weight & & & & & \\
$\quad$ Leaves & $0.168^{\mathrm{e}}$ & $0.222^{\mathrm{d}}$ & $0.390^{\mathrm{c}}$ & $0.480^{\mathrm{b}}$ & $0.560^{\mathrm{a}}$ \\
$\quad$ Stem & $0.103^{\mathrm{e}}$ & $0.129^{\mathrm{d}}$ & $0.138^{\mathrm{c}}$ & $0.270^{\mathrm{b}}$ & $0.391^{\mathrm{a}}$ \\
$\quad$ Root & $0.124^{\mathrm{e}}$ & $0.180^{\mathrm{d}}$ & $0.248^{\mathrm{c}}$ & $0.286^{\mathrm{b}}$ & $0.412^{\mathrm{a}}$ \\
\hline
\end{tabular}

Differences between group means with different letters in the same row are significant at $P \leq 0.05$.

from 1.0 to 4.0 meq S L ${ }^{-1}$. Further increase in sulfur supply caused decrease in biomass. The decrease in biomass was more due to sulfur deficiency. The yield reduction was more pronounced in sulfur deficient plants receiving $1 \mathrm{meq} \mathrm{S \textrm {L } ^ { - 1 }}$ and in excess plants grown at 8 meq S L ${ }^{-1}$ (Table 1). The plants treated with deficient and excess supply of sulfur showed a marked decrease in biomass. Deficient sulfur supply showed adverse effects on biomass of black gram, perhaps due to poor rate of photosynthesis which resulted in low yield. Sulfur deficiency decreased the level of Rubisco, leading to disturbance in carbon metabolism and low yield as earlier reported by [1]. Poor yield of sulfur excess plants could also be due to uncoupling of photophosphorylation caused by higher accumulation of sulfate ions in plants supplied with excess sulfur supply [30]. Tissue concentration of sulfur in leaves, stem, and root showed an increase with increasing sulfur supply. Leaves accumulated markedly higher sulfur than stem and roots. Compared to normal plants, the concentration of sulfur in leaves of plants grown with 1 and 2 meq S L $^{-1}$ was decreased by $63 \%$ and $40 \%$ while in stem it was decreased upto $50 \%$ and $25 \%$ respectively. Roots accumulated more sulfur than stem in plants grown with varying sulfur supply (Table 1). The delivery of sulfate into plastids for assimilation, sulfate storage in vacuoles, and the long distance transport organs in order to fulfill the source/sink demands during plant growth require specific sulfate transport proteins. Proton/sulfate cotransport in the plasma membrane of root cells is the first step for the uptake of sulfate. According to Smith et al. [31], sulfate uptake was resolved into saturable high affinity phase and nonsaturable low-affinity phase. The two distinct groupl transporters are different in their inducibilities in relation to the nutritional status of the plant. One transporter (Atsultr; 2) mediates the uptake of sulfate under both sulfur replete and sulfur-deficient conditions, and the expression is relatively insensitive to external sulfate concentrations. The second transporter (Atsult; 1) is highly inducible under limited sulfate conditions [32]. Sulfur limited condition does not increase the export of sulfur from mature leaves to young leaves which requires sulfur during development to attain full

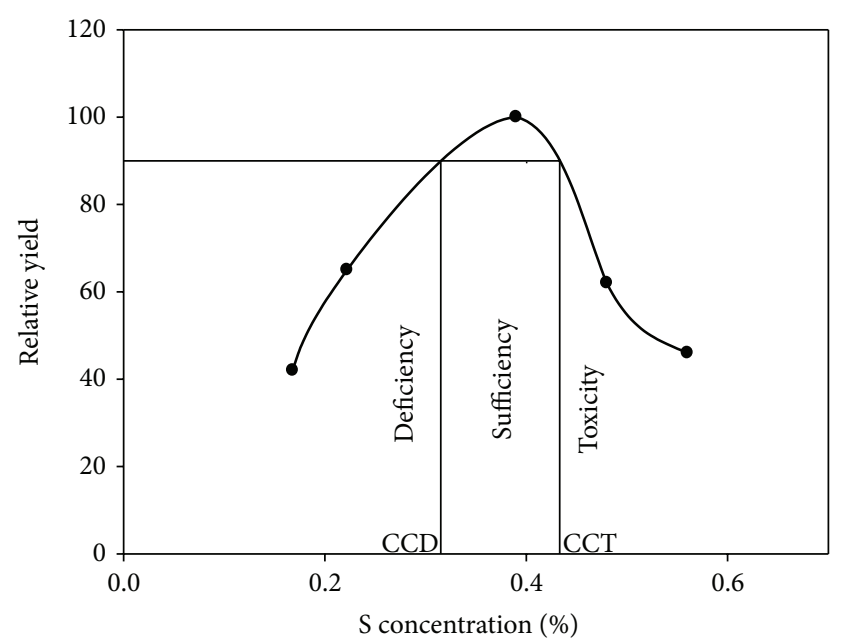

FIGURe 2: Plot of relative yield of black gram (Vigna mungo L. var. DPU-88-31) plants grown at varying levels of sulfur supply against tissue concentration in young leaves. CCD and CCT denote critical concentration for deficiency and toxicity, respectively. Differences between treatments means were compared using the probability level of $0.05(n=4)$.

expansion [33], and therefore the young leaves were smaller in size than the older ones. Plot of relative yield at harvest against concentration of sulfur in young leaves showed sulfur concentration between $0.315 \%$ and $0.434 \%$ to be optimum for yield. Concentration of nutrients corresponding to $90 \%$ of the optimal yield in the sub- and supra-optimal ranges were taken as critical concentration for deficiency (CCD) and toxicity (CCT), respectively. The thresholds for critical concentration of sulfur deficiency and toxicity were $0.315 \%$ and $0.434 \%$ dry weight for total yield (Figure 2).

3.3. Photoassimilatory Pigments. The photosynthetic pigments of leaves in black gram were found to be significantly decreased by sulfur stress and the decrease was more pronounced in the deficient plants than in excess plants as compared to normal (Table 2). Chlorophyll a, chl b, and total chl were decreased in plants supplied with deficient $(1$ and 2 meq S L ${ }^{-1}$ ) and excess sulfur ( 6 and 8 meq S L ${ }^{-1}$ ). Reduction in chlorophyll was observed in sulfur deficient plant which is in consonance with results of [1] in rice. In sulfur deficient plants, Chl a and Chl b were found to be affected more in comparison to sulfur excess plants. The $\mathrm{Chl} \mathrm{a} / \mathrm{b}$ ratio was significantly low at 1,2 , and 8 meq S L ${ }^{-1}$ supply. Chlorophyll $\mathrm{a} / \mathrm{b}$ ratio was also decreased by sulfur deficiency and toxicity suggesting that $\mathrm{Chl}$ a was more affected by sulfur stress than $\mathrm{Chl} \mathrm{b}$. Concentration of carotenoid was found to be depleted more in sulfur deficient plants in comparison to sulfur excess plants and an increase in Chl/Car ratio indicates that decrease in carotenoids was more than the chlorophylls (Table 2).

3.4. Carbohydrates and Cysteine. In leaves both reducing sugar and nonreducing sugar showed accumulation in sulfur stressed plants (Table 2). As compared to normal, the 
TABLE 2: Effect of graded level of sulfur supply on photoassimilatory pigments (chlorophylls and carotenoids), carbohydrates (sugars and starch), and cysteine in leaves of black gram plants at 28 days of growth.

\begin{tabular}{|c|c|c|c|c|c|}
\hline S supply: meq S L ${ }^{-1}$ & 1.0 & 2.0 & 4.0 & 6.0 & 8.0 \\
\hline \multicolumn{6}{|l|}{$\begin{array}{l}\text { Chlorophyll: } \mathrm{mg} \mathrm{g}^{-1} \\
\text { fresh weight }\end{array}$} \\
\hline Chl. $a$ & $0.328^{\mathrm{e}}$ & $0.507^{\mathrm{d}}$ & $0.704^{\mathrm{a}}$ & $0.671^{\mathrm{b}}$ & $0.541^{\mathrm{c}}$ \\
\hline Chl. $b$ & $0.199^{\mathrm{d}}$ & $0.306^{\mathrm{c}}$ & $0.358^{\mathrm{a}}$ & $0.339^{\mathrm{a}}$ & $0.287^{\mathrm{b}}$ \\
\hline Total Chl. & $0.507^{\mathrm{d}}$ & $0.813^{c}$ & $1.062^{\mathrm{a}}$ & $1.011^{\mathrm{b}}$ & $0.828^{c}$ \\
\hline Chl $a / b$ & $1.648^{\mathrm{c}}$ & $1.656^{\mathrm{c}}$ & $1.966^{\mathrm{a}}$ & $1.971^{\mathrm{a}}$ & $1.882^{\mathrm{b}}$ \\
\hline \multicolumn{6}{|l|}{$\begin{array}{l}\text { Carotenoids: } \mathrm{mg} \mathrm{g}^{-1} \\
\text { fresh weight }\end{array}$} \\
\hline Car & $0.245^{\mathrm{d}}$ & $0.361^{c}$ & $0.537^{\mathrm{a}}$ & $0.489^{\mathrm{b}}$ & $0.386^{\mathrm{c}}$ \\
\hline Chl/Car & $2.091^{\mathrm{d}}$ & $2.250^{\mathrm{b}}$ & $1.978^{\mathrm{a}}$ & $2.067^{\mathrm{d}}$ & $2.147^{\mathrm{c}}$ \\
\hline \multicolumn{6}{|l|}{$\begin{array}{l}\text { Carbohydrates: \% fresh } \\
\text { weight }\end{array}$} \\
\hline Reducing sugar & $0.093^{\mathrm{c}}$ & $0.085^{\mathrm{d}}$ & $0.076^{\mathrm{e}}$ & $0.120^{\mathrm{a}}$ & $0.100^{\mathrm{b}}$ \\
\hline Nonreducing sugar & $0.082^{\mathrm{a}}$ & $0.080^{\mathrm{a}}$ & $0.022^{c}$ & $0.057^{\mathrm{b}}$ & $0.025^{\mathrm{c}}$ \\
\hline Total sugar & $0.175^{\mathrm{a}}$ & $0.165^{\mathrm{b}}$ & $0.098^{\mathrm{d}}$ & $0.177^{\mathrm{a}}$ & $0.125^{\mathrm{c}}$ \\
\hline Starch & $2.530^{\mathrm{a}}$ & $1.915^{\mathrm{c}}$ & $0.960^{\mathrm{e}}$ & $1.725^{\mathrm{d}}$ & $2.415^{\mathrm{b}}$ \\
\hline \multicolumn{6}{|l|}{$\begin{array}{l}\text { Cysteine: mM } 100 \mathrm{mg}^{-1} \\
\text { fresh weight }\end{array}$} \\
\hline Cysteine & $0.081^{\mathrm{e}}$ & $0.119^{d}$ & $0.148^{\mathrm{c}}$ & $0.199^{\mathrm{b}}$ & $0.227^{\mathrm{a}}$ \\
\hline
\end{tabular}

Differences between group means with different letters in the same row are significant at $P \leq 0.05$.

accumulation of nonreducing sugars was more in sulfur deficient than sulfur excess plants whereas the reducing sugar was significantly increased more under excess sulfur. The accumulation of sugar is probably due to poor translocation resulting in poor growth and development. Starch was also accumulated in sulfur stressed plants especially in sulfur deficient plants (Table 2). Accumulation of starch is known to be a general response to nutrient deficiency and indicates that the utilization of carbohydrates is restricted under stress conditions. Starch metabolism is dependent on Fd:thioredoxin system because oxidized Fd:thioredoxin system regulates both starch synthesis and its degradation [34]. Thioredoxin is the main switch for the regulation of carbon assimilation by changing the thiol disulphide redox state [35]. In sulfur stressed plants the utilization of starch by plants is thus inhibited resulting in its accumulation. Cysteine content in leaves of blackgram plants was found to be significantly decreased in sulfur deficient plants in comparison to normal plants (Table 2) which is in accordance with the Hawkesford and de Kok [36]. In sulfur excess plants cysteine concentration increased in leaves and accumulated to $153 \%$ of normal in plants receiving 8 meq $\mathrm{S} \mathrm{L}^{-1}$.

3.5. $\mathrm{H}_{2} \mathrm{O}_{2}$ and TBARS. The present study shows that sulfur stress influences the oxidative metabolism in black gram. Compared with normal, sulfur stress markedly increased the
ROS content sulfur deficient and excess plants as observed by the increase in $\mathrm{H}_{2} \mathrm{O}_{2}$ concentration in leaves of these plants. This result was in consonance with reports of [37]. The increased concentration of $\mathrm{O}_{2}{ }^{--}$and $\mathrm{H}_{2} \mathrm{O}_{2}$ causes lipid peroxidation leading to membrane damage and leakage of electrolytes [6]. The lipid peroxidation was significantly high at all levels particularly at 1 and 2 meq $\mathrm{S} \mathrm{L}^{-1}$ supply. In sulfur excess plants, it was somewhat lower than in sulfur deficient plants. Maximum increase in TBARS concentration was found in plants supplied with $1 \mathrm{meq} \mathrm{S} \mathrm{L}{ }^{-1}$ (Figure 3). TBARS is a product of cell membrane lipid peroxidation and its content in vivo can indicate the extent of oxidative stress in plants and cell membrane homeostasis. Present results showed that sulfur stress caused a pronounced increase in TBARS content and hence lipid peroxidation. The accumulation of TBARS was more in sulfur deficient in comparison to sulfur toxic plants indicating that the former is more susceptible to oxidative damage than the latter.

3.6. Ascorbate and NPT. Plants consist of an array of protective mechanism and repair systems that can minimize the occurrence of oxidative damage caused by ROS [4]. Among the antioxidants, nonprotein thiols and ascorbate not only act as substrate for GR and APX, but also are directly involved in ROS scavenging [10]. Ascorbic acid is main ROS detoxifying compound in aqueous phase as it donates electrons in a wide range of enzymatic and nonenzymatic reactions. Ascorbic acid can directly scavenges superoxide, hydroxyl radicals, and singlet oxygen and reduce $\mathrm{H}_{2} \mathrm{O}_{2}$ to water through ascorbate peroxidase reaction. Ascorbate is a primary and also a powerful secondary antioxidant. Ascorbate also regenerates the lipophilic antioxidants $\alpha$ - tocopherol [12] and it removes $\mathrm{H}_{2} \mathrm{O}_{2}$ from chloroplast as chloroplast lacks catalase [38]. Enhanced concentration of ascorbic acid as observed in the present study has been reported as a consequence of sulfur stress in plants [38]. In sulfur excess plants the ascorbate levels were lower than deficient plants probably due to higher APX activity in the former (Figure 3). Nonprotein thiols which include GSH are found in most plants and act as important antioxidants [9]. Glutathione is the main storage form of sulfur and low sulfur concentration in plants would result in its depletion. The NPT concentration was reduced in sulfur deficient plants as compared to normal which is in accordance with the findings of [1]. Nonprotein thiol content was increased with increase in sulfur supply and plays a significant role in defense against oxidative damage (Figure 3). Earlier GSH was also found to be increased in plants exposed to $\mathrm{SO}_{2}[13]$.

3.7. Antioxidative Enzymes. The induction of ROS scavenging enzymes, such as superoxide dismutase (SOD), catalase (CAT), peroxidase (POD), ascorbate peroxidase (APX), and glutathione reductase (GR), formed during stress response, is important for the detoxification of ROS. The plants supplied with sulfur deficient and excess supply influenced the activity of antioxidative enzymes in black gram to varying extent. In the present study compared to control, sulfur deficient and excess plants showed higher activities of CAT, POD, 


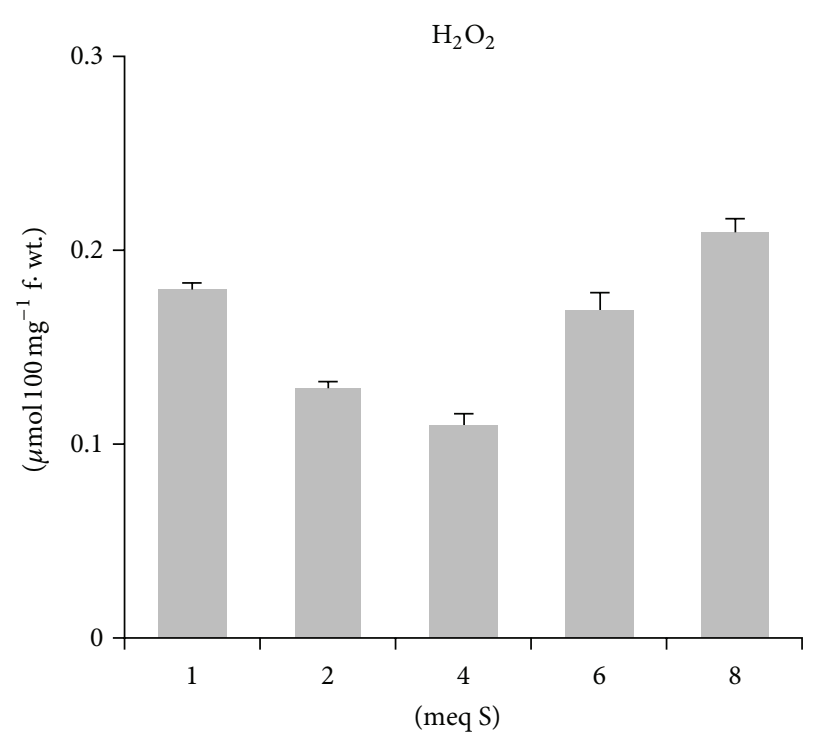

(a)

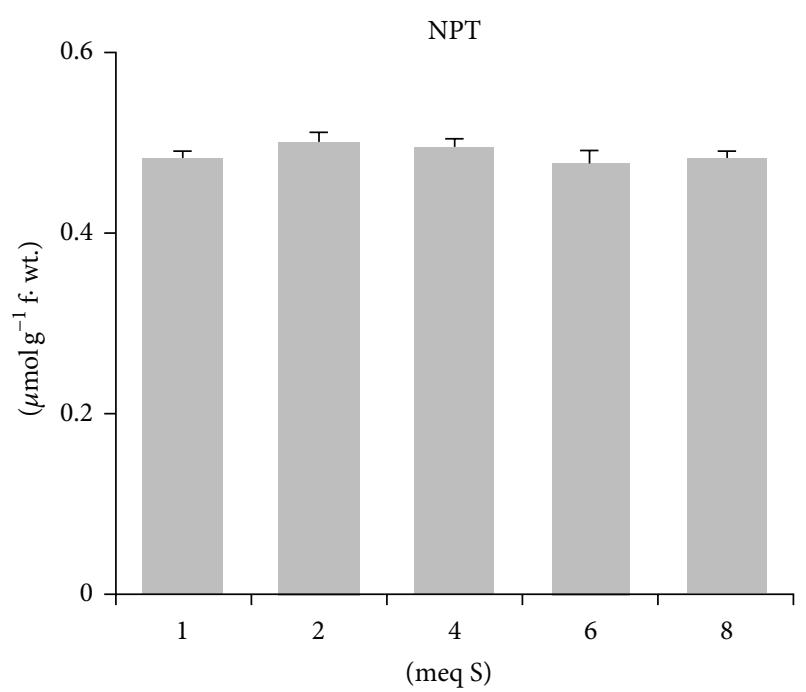

(c)

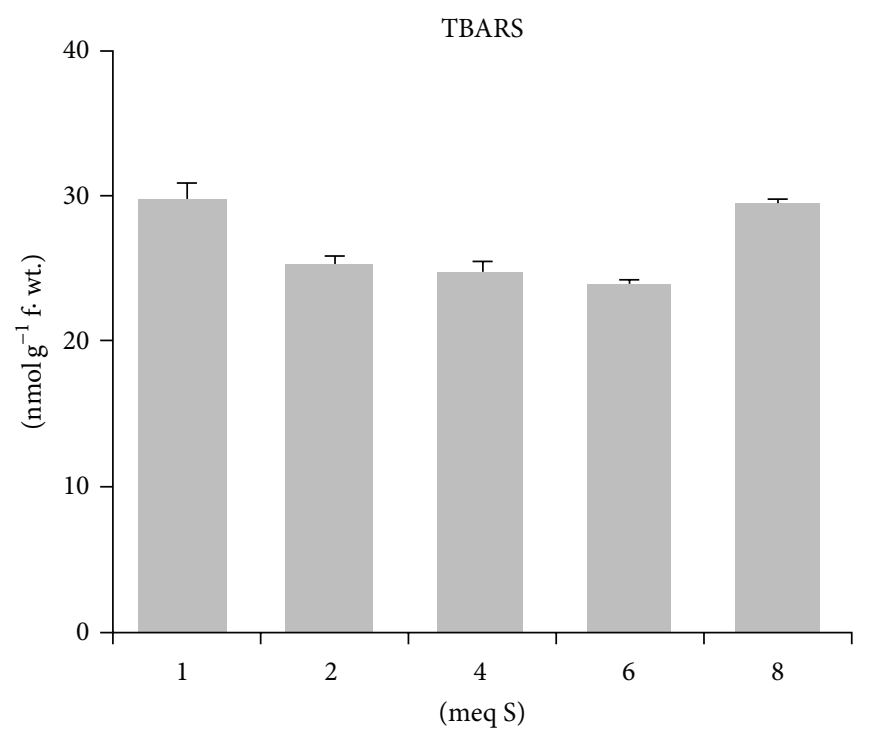

(b)

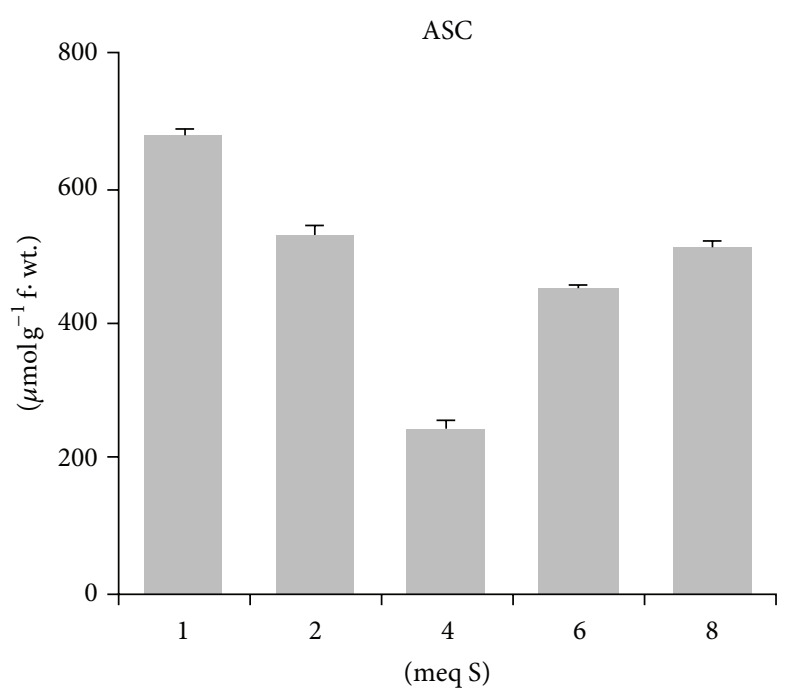

(d)

FIGURE 3: Effect of variable sulfur supply on the concentration of hydrogen peroxide $\left(\mathrm{H}_{2} \mathrm{O}_{2}\right)$ and thiobarbituric acid reactive substances (TBARS), nonprotein thiols (NPT), and ascorbate (ASC) at 28 days of growth in leaves of black gram plants (Vigna mungo L.). (Levels, meq S L $-1.0,2.0,4.0,6.0$, and 8.0). Data represent mean \pm S.E. $(P \leq 0.05)$.

SOD, APX, and GR (Figures 4 and 5). Activity of SOD was found significantly higher in plants grown under $1 \mathrm{meq} \mathrm{S} \mathrm{L}{ }^{-1}$ as well as plants grown with 6 and $8 \mathrm{meq} \mathrm{S} \mathrm{L}^{-1}$. Activities of CAT and POD were more enhanced in sulfur excess plants than in deficient plants. Superoxide dismutase constitutes the first line of defense against reactive oxygen species and dismutates the highly toxic $\mathrm{O}_{2}{ }^{--}$to $\mathrm{H}_{2} \mathrm{O}_{2}$ [8]. Superoxide dismutase was increased in sulfur deficient plants which are in consonance with reports of [37]. Superoxide dismutase in sulfur excess plants was increased to a greater extent than in deficient plants. This increase in SOD activity by sulfur toxicity in plants has been observed earlier by $\mathrm{SO}_{2}$ fumigation [13]. Catalase and ascorbate peroxidase are involved in the removal of $\mathrm{H}_{2} \mathrm{O}_{2}$ [39]. Catalase converts $\mathrm{H}_{2} \mathrm{O}_{2}$ to water and molecular oxygen. Increment in CAT and POD activity under deficiency as observed in current work was also reported earlier [40]. Catalase and peroxidase activity was more enhanced under excess sulfur than deficiency resulting in more detoxification of $\mathrm{H}_{2} \mathrm{O}_{2}$ produced by high SOD activity in these plants (Figure 4). Ascorbate peroxidase also showed a similar trend and its activity was more enhanced in sulfur excess plants than in the deficient plants (Figure 5). Thus $\mathrm{H}_{2} \mathrm{O}_{2}$ concentration was less in sulfur excess plants than in the deficient ones.

Glutathione reductase is an important enzyme in the ascorbate-glutathione cycle and helps to maintain the level of reduced glutathione for the regeneration of ascorbate required for breakdown of $\mathrm{H}_{2} \mathrm{O}_{2}$ by APX [11]. An increase 


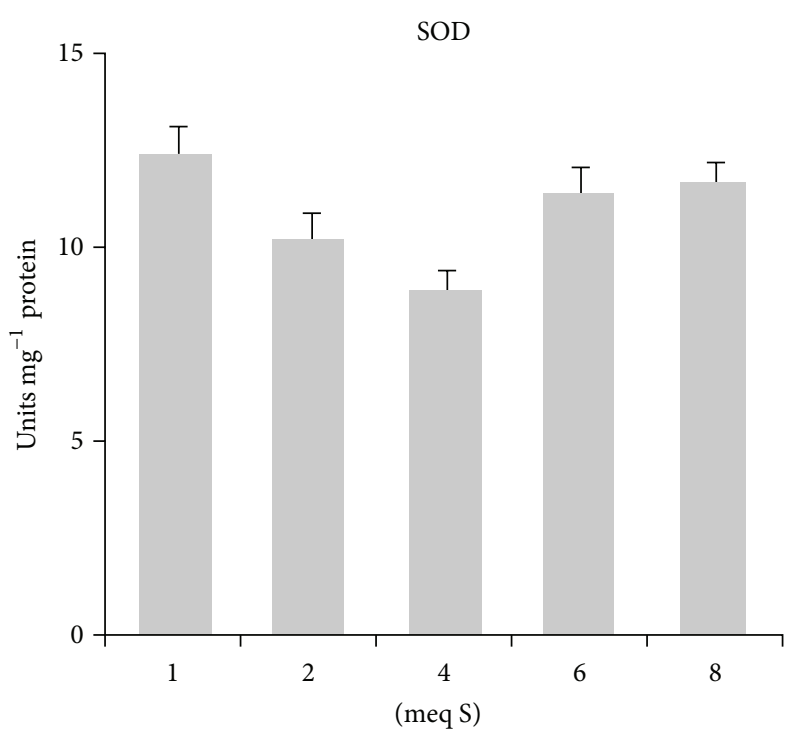

(a)

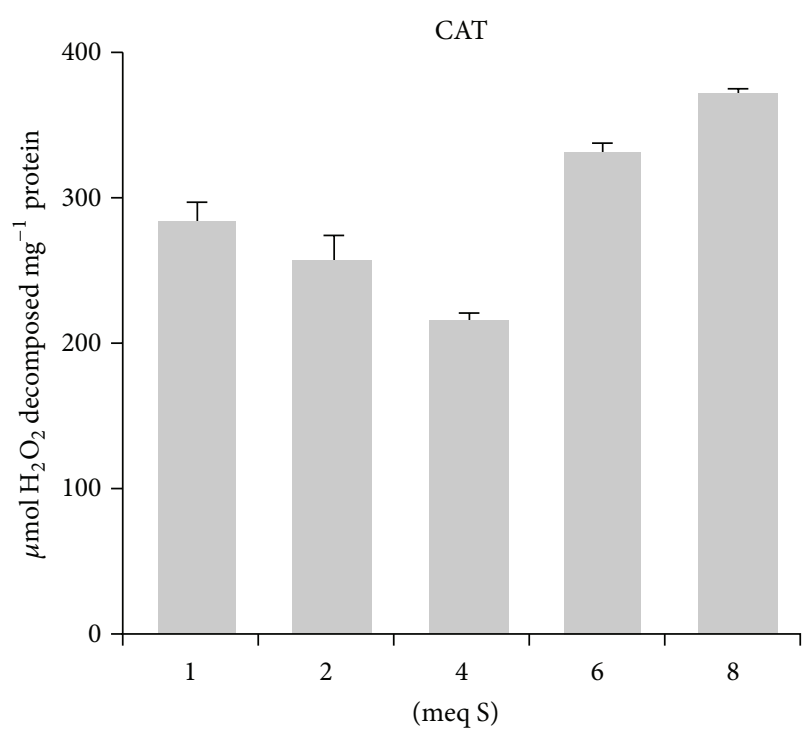

(b)

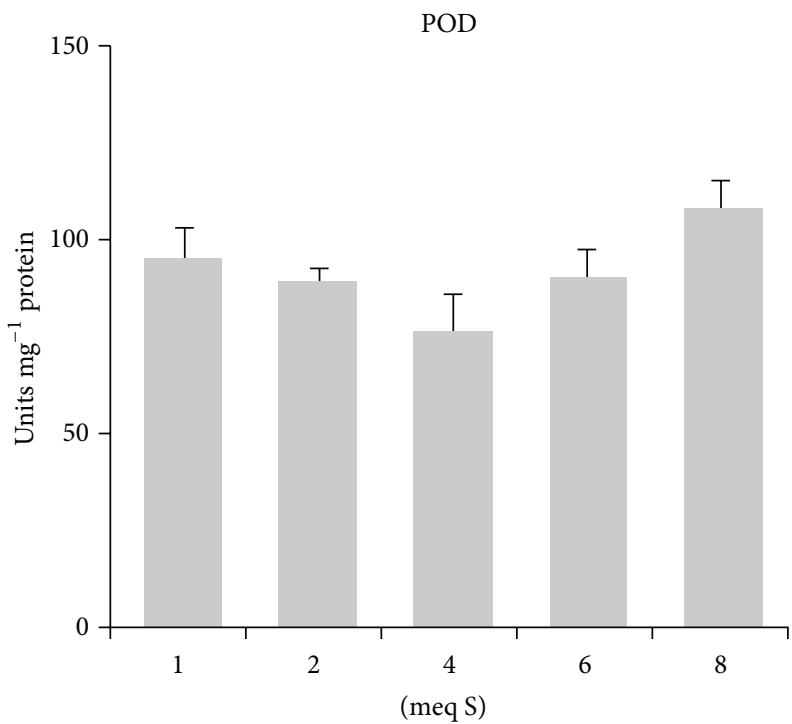

(c)

FIGURE 4: Effect of graded levels of sulfur supply on activity of superoxide dismutase, (SOD), catalase (CAT), and peroxidase (POD) at 28 days of growth in leaves of black gram plants (Vigna mungo L.). (Levels, meq S L ${ }^{-1}-1.0,2.0,4.0,6.0$, and 8.0.) Data represent mean \pm S.E. $(P \leq 0.05)$.

in the activity of GR was observed at all levels of sulfur supply when compared to normal (Figure 5). The increase in activity of GR was found to be more significant in plants severely deficient in sulfur $\left(1 \mathrm{meq} \mathrm{S} \mathrm{L}^{-1}\right)$ in comparison to sulfur excess plants; however, it could not regenerate GSH which remained low in these plants probably due to low levels of cysteine which is required for synthesis of GSH. Exposure of sulfur as $\mathrm{SO}_{2}$ also showed an increase in the activity of GR [13] which helps in maintaining the level of the antioxidant GSH. The upregulation of all antioxidative enzymes was to a greater extent in the sulfur toxic plants which also contained higher concentration of ascorbate and NPT than the deficient ones. This probably reduces the extent of oxidative damage in toxic plants as is apparent from the lower accumulation of TBARS than in the deficient plants.

In conclusion, in the present study we observed that the effect of sulfur deficiency was more pronounced than excess sulfur as is apparent from higher accumulation of $\mathrm{H}_{2} \mathrm{O}_{2}$ and TBARS leading to more severe lipid peroxidation in the former. This severity of oxidative damage in sulfur deficient plants appears to be a consequence of lower activity of CAT, POD, and APX than in toxic plants. Inability of the sulfur deficient plants to restore the levels of NPT levels as observed in sulfur excess plants also increases the oxidative damage in these plants. 
APX

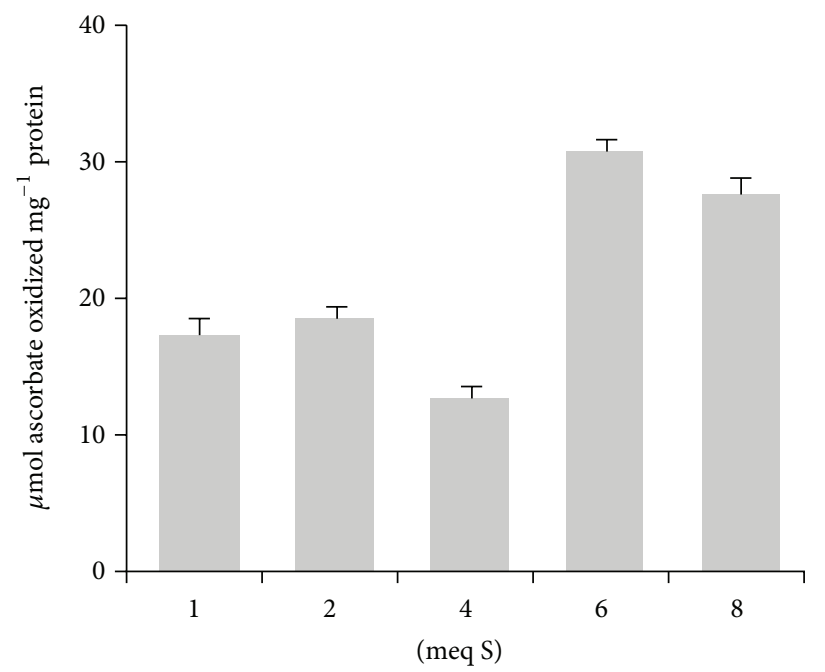

(a)
GR

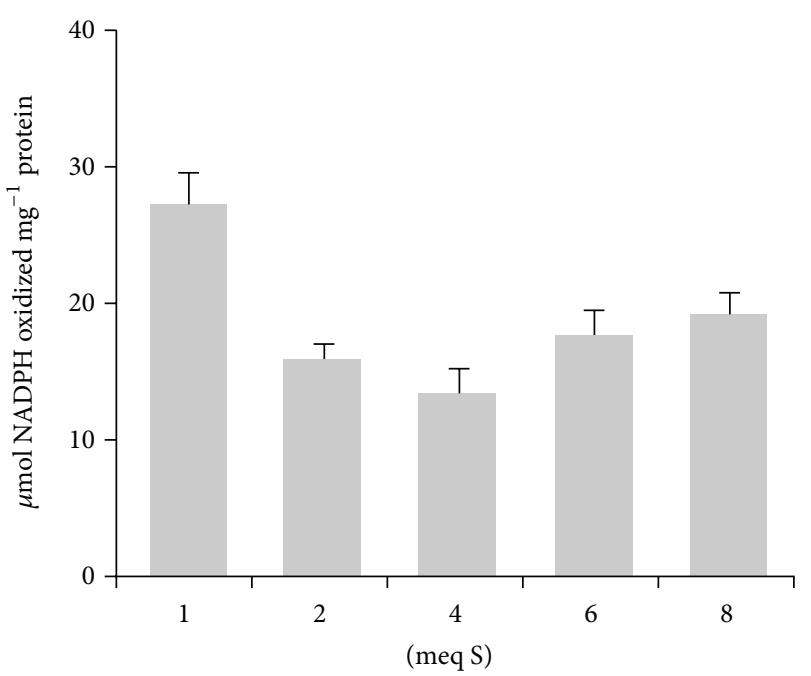

(b)

FIGURE 5: Effect of graded levels of sulfur supply on activity of ascorbate peroxidase (APX) and glutathione reductase (GR) at 28 days in leaves of black gram plants (Vigna mungo L.). (Levels, meq S L ${ }^{-1}-1.0,2.0,4.0,6.0$, and 8.0.) Data represent mean \pm S.E. $(P \leq 0.05)$.

\section{Conflict of Interests}

The authors declare that there is no conflict of interests regarding the publication of this paper.

\section{References}

[1] C. Lunde, A. Zygadlo, H. T. Simonsen, P. L. Nielsen, A. Blennow, and A. Haldrup, "Sulfur starvation in rice: the effect on photosynthesis, carbohydrate metabolism, and oxidative stress protective pathways," Physiologia Plantarum, vol. 134, no. 3, pp. 508-521, 2008.

[2] T. Leustek and K. Saito, "Sulfate transport and assimilation in plants," Plant Physiology, vol. 120, no. 3, pp. 637-643, 1999.

[3] H. Rennenberg, "Glutathione metabolism and possible biological roles in higher plants," Phytochemistry, vol. 21, no. 12, pp. 2771-2781, 1980.

[4] K. Apel and H. Hirt, "Reactive oxygen species: metabolism, oxidative stress, and signal transduction," Annual Review of Plant Biology, vol. 55, pp. 373-399, 2004.

[5] A. Caro and S. Puntarulo, "Effect of in vivo iron supplementation on oxygen radical production by soybean roots," Biochimica et Biophysica Acta, vol. 1291, no. 3, pp. 245-251, 1996.

[6] B. Halliwell and J. M. C. Gutteridge, Free Radicals in Biology and Medicine, Oxford University Press, Oxford, UK, 4th edition, 2007.

[7] O. Blokhina, E. Virolainen, and K. V. Fagerstedt, "Antioxidants, oxidative damage and oxygen deprivation stress: a review," Annals of Botany, vol. 91, no. 2, pp. 179-194, 2003.

[8] C. Bowler, M. van Montagu, and D. Inzé, "Superoxide dismutase and stress tolerance," Annual Review of Plant Physiology and Plant Molecular Biology, vol. 43, no. 1, pp. 83-116, 1992.

[9] K. Asada, "Ascorbate peroxidase-a hydrogen peroxidescavenging enzyme in plants," Physiologia Plantarum, vol. 85, no. 2, pp. 235-241, 1992.
[10] C. H. Foyer, H. L. Delgado, J. F. Dat, and I. M. Scott, "Hydrogen peroxide- and glutathione-associated mechanisms of acclimatory stress tolerance and signalling," Physiologia Plantarum, vol. 100, no. 2, pp. 241-254, 1997.

[11] C. H. Foyer and B. Halliwell, "The presence of glutathione and glutathione reductase in chloroplasts: a proposed role in ascorbic acid metabolism," Planta, vol. 133, no. 1, pp. 21-25, 1976.

[12] N. Smirnoff, "Ascorbic acid: metabolism and functions of a multi-facetted molecule," Current Opinion in Plant Biology, vol. 3, no. 3, pp. 229-235, 2000.

[13] G. Soldatinl, A. Ranieri, L. Lencioni, and G. Lorenzini, "Effects of continuous $\mathrm{SO}_{2}$ fumigation on $\mathrm{SH}$-containing compounds in two wheat cultivars of different sensitivities," Journal of Experimental Botany, vol. 43, no. 6, pp. 797-801, 1992.

[14] N. Pandey, B. Gupta, and G. C. Pathak, "Antioxidant responses of pea genotypes to zinc deficiency," Russian Journal of Plant Physiology, vol. 59, no. 2, pp. 198-205, 2012.

[15] L. Chesnin and C. H. Yien, "Turbidimetric determination of available sulphates," Soil Science and Society of American Proceedings, vol. 15, pp. 149-151, 1951.

[16] H. K. Lichtenthaler, "Chlorophylls and carotenoids: pigments of photosynthetic biomembranes," in Methods in Enzymology, L. Packer and R. Douce, Eds., pp. 350-382, Academic Press, New York, NY, USA, 1987.

[17] N. Nelson, "Photometric adaptation of Somogyi's method for determination of glucose," Journal of Biological Chemistry, vol. 53, pp. 375-378, 1944.

[18] R. Montgomery, "Determination of glycogen," Archives of Biochemistry and Biophysics, vol. 67, no. 2, pp. 378-386, 1957.

[19] M. K. Gaitonde, "A spectrophotometric method for the direct determination of cysteine in the presence of other naturally occurring amino acids," Biochemical Journal, vol. 104, no. 2, pp. 627-633, 1967.

[20] T. Brennan and C. Frenkel, "Involvement of hydrogen peroxide in the regulation of senescence in pear," Plant Physiology, vol. 59, no. 3, pp. 411-416, 1977. 
[21] R. L. Heath and L. Packer, "Photoperoxidation in isolated chloroplasts: I. kinetics and stoichiometry of fatty acid peroxidation," Archives of Biochemistry and Biophysics, vol. 125, no. 1, pp. 189-198, 1968.

[22] M. Y. Law, S. A. Charles, and B. Halliwell, "Glutathione and ascorbic acid in spinach (Spinacia oleracea) chloroplasts. The effect of hydrogen peroxide and of Paraquat," Biochemical Journal, vol. 210, no. 3, pp. 899-903, 1983.

[23] G. L. Ellman, “Tissue sulphydryl groups," Archives of Biochemistry and Biophysics, vol. 82, no. 1, pp. 70-77, 1959.

[24] H. V. Euler and K. Josephson, "Über katalase. I," Justus Liebigs Annalen der Chemie, vol. 452, no. 1, pp. 158-181, 1927.

[25] M. Luck, "Peroxidase," in Methods of Enzymic Analysis, H. V. Bergmeyer, Ed., pp. 895-897, Academic Press, New York, NY, USA, 1963.

[26] C. Beauchamp and I. Fridovich, "Superoxide dismutase: improved assays and an assay applicable to acrylamide gels," Analytical Biochemistry, vol. 44, no. 1, pp. 276-287, 1971.

[27] Y. Nakano and K. Asada, "Hydrogen peroxide is scavenged by ascorbate-specific peroxidase in spinach chloroplasts," Plant and Cell Physiology, vol. 22, no. 5, pp. 867-880, 1981.

[28] R. Mittler and B. A. Zilinskas, "Regulation of pea cytosolic ascorbate peroxidase and other antioxidant enzymes during the progression of drought stress and following recovery from drought," Plant Journal, vol. 5, no. 3, pp. 397-405, 1994.

[29] J. B. Sinclair, "Soybeans," in Nutrient Deficiencies and Toxicities in Crop Plants, W. F. Bennett, Ed., pp. 99-103, APS Press, St. Paul, Minn, USA, 1993.

[30] K. Mengel and E. A. Kirkby, Principles of Plant Nutrition, The International Potash Institute, Bern, Switzerland, 4th edition, 1987.

[31] F. W. Smith, P. M. Ealing, M. J. Hawkesford, and D. T. Clarkson, "Plant members of a family of sulfate transporters reveal functional subtypes," Proceedings of the National Academy of Sciences of the United States of America, vol. 92, no. 20, pp. 93739377, 1995.

[32] J. R. Howarth, P. Fourcroy, J.-C. Davidian, F. W. Smith, and M. J. Hawkesford, "Cloning of two contrasting high-affinity sulfate transporters from tomato induced by low sulfate and infection by the vascular pathogen Verticillium dahliae," Planta, vol. 218, no. 1, pp. 58-64, 2003.

[33] I. G. K. Adiputra and J. W. Anderson, "Effect of sulphur nutrition on redistribution of sulphur in vegetive barley," Physiologia Plantarum, vol. 95, no. 4, pp. 643-650, 1995.

[34] B. B. Buchanan and Y. Balmer, "Redox regulation: a broadening horizon," Annual Review of Plant Biology, vol. 56, pp. 187-220, 2005.

[35] P. Geigenberger, A. Kolbe, and A. Tiessen, "Redox regulation of carbon storage and partitioning in response to light and sugars," Journal of Experimental Botany, vol. 56, no. 416, pp. 1469-1479, 2005.

[36] M. J. Hawkesford and L. J. de Kok, "Managing sulphur metabolism in plants," Plant, Cell \& Environment, vol. 29, no. 3, pp. 382-395, 2006.

[37] R. K. Tewari, P. Kumar, N. Tewari, S. Srivastava, and P. N. Sharma, "Macronutrient deficiencies and differential antioxidant responses-influence on the activity and expression of superoxide dismutase in maize," Plant Science, vol. 166, no. 3, pp. 687-694, 2004.

[38] H. Mehlhorn, G. Seufert, A. Schmidt, and K. J. Kunert, "Effect of $\mathrm{SO}_{2}$ and $\mathrm{O}_{3}$ on production of antioxidants in conifers," Plant Physiology, vol. 82, no. 1, pp. 336-338, 1986.
[39] S. S. Gill and N. Tuteja, "Reactive oxygen species and antioxidant machinery in abiotic stress tolerance in crop plants," Plant Physiology and Biochemistry, vol. 48, no. 12, pp. 909-930, 2010.

[40] R. N. Kumawat, P. S. Rathore, N. S. Nathawat, and M. Mahatma, "Effect of sulfur and iron on enzymatic activity and chlorophyll content of mungbean," Journal of Plant Nutrition, vol. 29, no. 8, pp. 1451-1467, 2006. 

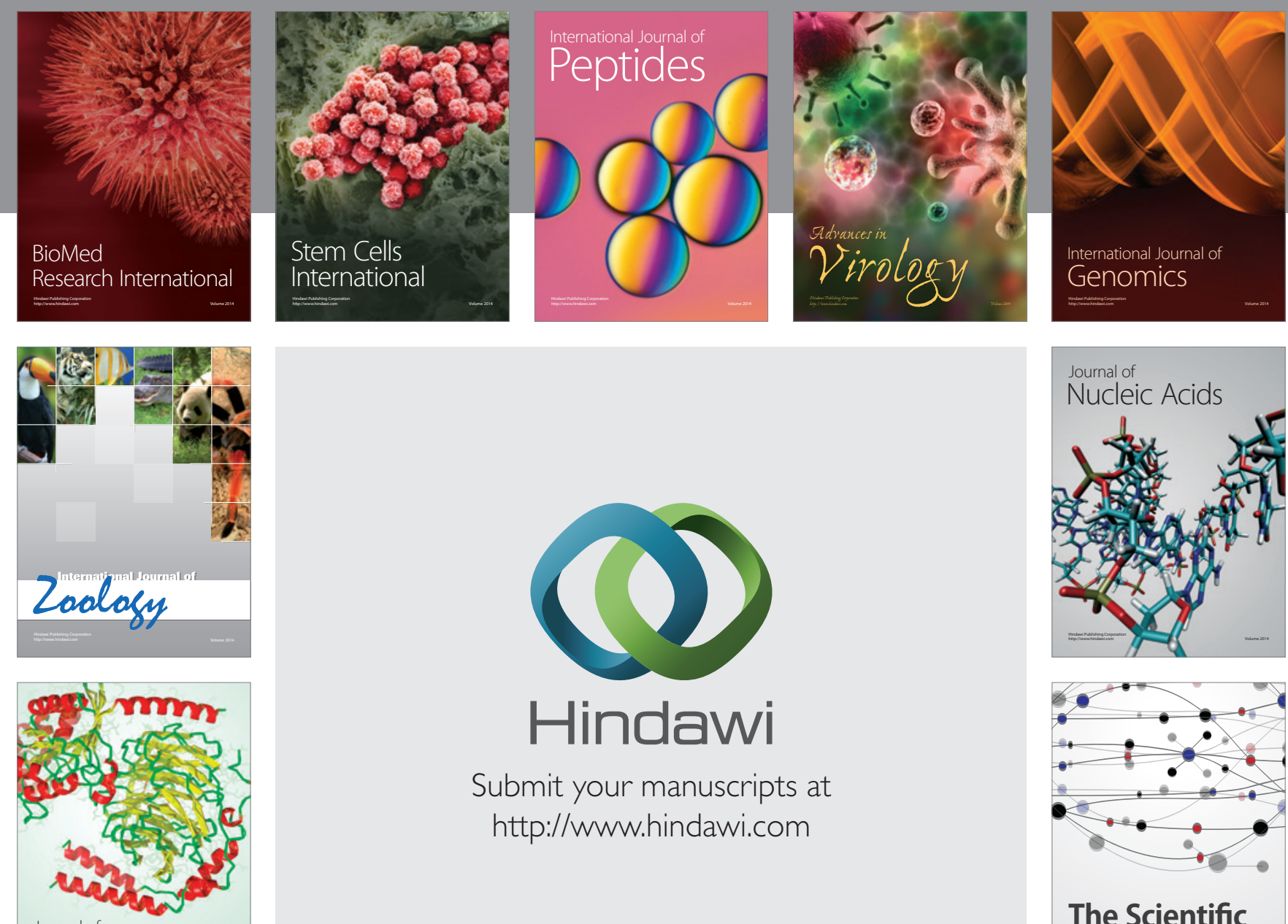

Submit your manuscripts at

http://www.hindawi.com

Journal of
Signal Transduction
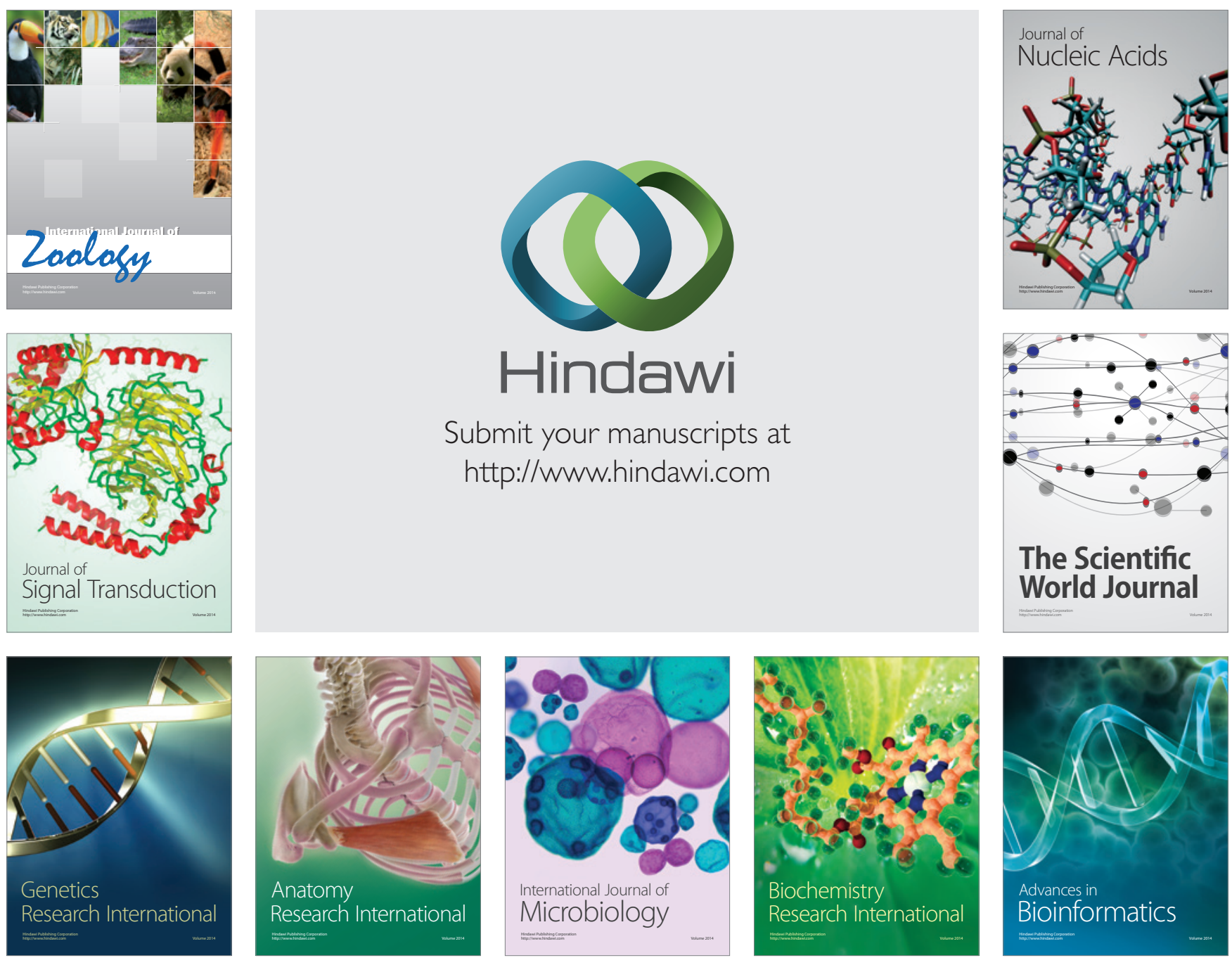

The Scientific World Journal
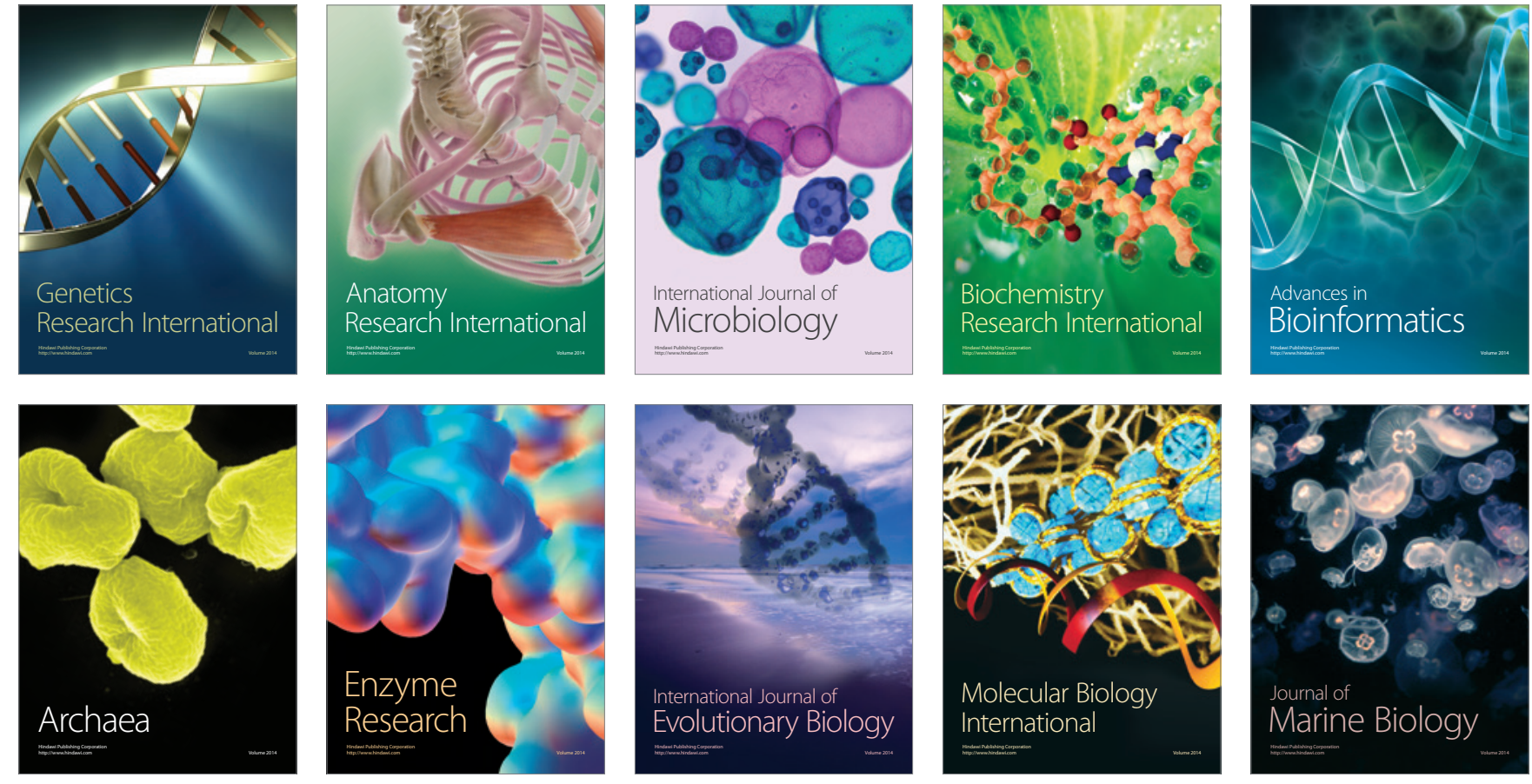